\title{
Tahapan Menentukan Diagnosa Keperawatan
}

\section{Yosepine Megawati}

\author{
yosepinemegawati28@gmail.com
}

\section{LATAR BELAKANG}

Dalam memberikan asuhan keperawatan kepada klien, perawat pasti akan melalui tahapan proses keperawatan (nursing process) yang meliputi tahap pengkajian, diagnosa, perencanaan, pelaksanaan dan evaluasi.Setalah melakukan pengkajian keperawatan, perawat diwajibkan menentukan diagnosa keperawatan berdasarkan data yang didapatkan dari klien baik dari hasil wawancara, pemeriksaan fisik, catatan medis dan pemeriksaan laboratorium. Penentuan diagnosa keperawatan sangat penting, karena akan memengaruhi tindakan keperawatan yang perawat akan berikan. Setelah merumuskan diagnosa keperawatan spesifik, perawat harus berpikir kritis guna menentukan tingkat prioritas diagnosa dengan membuat peringkat.

Secara etimologi, diagnosis berasal dari bahasa Yunani, yaitu gnosis yang berarti ilmu pengetahuan. Sedangkan secara terminologi, pengertian diagnosis adalah penetapan suatu keadaan yang menyimpang atau keadaan normal melalui dasar pemikiran dan pertimbangan ilmu pengetahuan. Diagnosis Keperawatan adalah suatu penilaian klinis mengenai respon klien terhadap masalah kesehatan atau proses kehidupan yang dialaminya baik yang berlangsung aktual maupun potensial. Diagnosis keperawatan ini bertujuan untuk mengidentifikasi respon klien individu, keluarga dan komunitas terhadap situasi yang berkaitan dengan kesehatan. Responrespon tersebut merupakan reaksi terhadap masalah kesehatan dan proses kehidupan yang dialami klien. Sehingga, diharapkan perawat mampu menangkap dan berfikir kritis dalam merespon perilaku tersebut.

Profesi perawat menggunakan proses keperawatan (nursing process) sebagai kerangka pikir dan kerangka kerja dalam merawat pasien. Keperawatan sebagai proses, diperkenalkan sejak tahun 1955 oleh Hall dan pada tahun 2004 proses keperawatan (nursing process) ditetapkan sebagai series of steps oleh ANA (American Nursing Association) (Wilkinson, 2007), yang terdiri dari pengkajian, penetapan diagnosa, perencanaan hasil, perencanaan intervensi, implementasi dan evaluasi. 


\section{METODE}

Metode yang digunakan adalah metode kualitatif. Metode kualitatif adalah metode riset yang sifatnya memberikan penjelasan dengan menggunakan analisis. Menurut Sugiyono (2011), metode penelitian kualitatif adalah metode penelitian yang berlandaskan pada filsafat post positivisme, digunakan untuk meneliti pada kondisi obyek yang alamiah, (sebagai lawannya eksperimen) dimana peneliti adalah sebagai instrumen kunci, pengambilan sampel sumber data dilakukan secara purposive dan snowball, teknik pengumpulan dengan tri-anggulasi (gabungan), analisis data bersifat induktif atau kualitatif, dan hasil penelitian kualitatif lebih menekankan makna dari pada generalisasi.

\section{HASIL}

Diagnosis Keperawatan adalah suatu penilaian klinis mengenai respon klien terhadap masalah kesehatan atau proses kehidupan yang dialaminya baik yang berlangsung aktual maupun potensial.

Tujuan dari diagnosis keperawatan adalah untuk mengidentifikasi respon klien individu, keluarga dan komunitas terhadap situasi yang berkaitan dengan kesehatan

Diagnosis keperawatan dan diagnosis medis tidak sama namun saling berkaitan. Perbedaan diagnosa keperawatan dan diagnosa medis, Diagnosa keperawatan berfokus pada dan mengidentifikasi kebutuhan keperawatan dari klien. Diagnosa keperawatan mencerminkan tingkat

kesehatan atau respons terhadap penyakit atau proses patologis, status emosional, fenomena sosiokultural, atau atau tahap perkembangan, sementara itu diagnosa medis (kedokteran) secara menonjol mengidentifikasi status penyakit spesifik. Fokus medis adalah pada diagnosis dan pengobatan terhadap penyakit.

Diagnosis keperawatan memiliki 2 komponen utama, yaitu Masalah (Problem) atau Label Diagnosis dan Indikator Diagnostik.

1. Masalah (Problem)

Masalah merupakan label diagnosis keperawatan yang menggambarkan inti dari respon klien terhadap kondisi kesehatan atau proses kehidupannya.

2. Indikator Diagnostik 
Indikator diagnostik terdiri dari penyebab, tanda/gejala, dan faktor resiko.

Proses penerapan diagnosis (diagnostic process) adalah suatu proses yang sistematis yang terdiri dari 3 tahap yaitu, analisis data, identifikasi masalah dan perumusan diagnosis.

Sistem Klasifikasi diagnosa keperawatan salah satunya adalah NANDA (North American Nursing Diagnoses Association), Dalam NANDA tersebut terdapat Sembilan pola respon manusia: pertukaran, berkomunikasi, berhubungan, menilai, memilih, pergerakkan, persepsi, mengetahui, dan perasaan. Akan tetapi, NANDA belum optimal mengakomodasikan diagnosis keperawatan di area keperawatan komunitas (kelompok dan masyarakat), sehingga digunakan juga rumusan ICNP (International Classification for Nursing Practice). ICNP membagi diagnosis keperawatan menjadi 5 kategori, yaitu Fisiologis, Psikologis, Perilaku, Relasional dan Lingkungan.

\section{PEMBAHASAN}

Diagnosis Keperawatan adalah suatu penilaian klinis mengenai respon klien terhadap masalah kesehatan atau proses kehidupan yang dialaminya baik yang berlangsung aktual maupun potensial. Diagnosis keperawatan ini bertujuan untuk mengidentifikasi respon klien individu, keluarga dan komunitas terhadap situasi yang berkaitan dengan kesehatan. Respon-respon tersebut merupakan reaksi terhadap masalah kesehatan dan proses kehidupan yang dialami klien. Sehingga, diharapkan perawat mampu menangkap dan berfikir kritis dalam merespon perilaku tersebut. Perbedaan diagnosa keperawatan dan diagnosa medis, Diagnosa keperawatan berfokus pada dan mengidentifikasi kebutuhan keperawatan dari klien. Diagnosa keperawatan mencerminkan tingkat kesehatan atau respons terhadap penyakit atau proses patologis, status emosional, fenomena sosiokultural, atau atau tahap perkembangan, sementara itu diagnosa medis (kedokteran) secara menonjol mengidentifikasi status penyakit spesifik. Fokus medis adalah pada diagnosis dan pengobatan terhadap penyakit.

Karakteristik dari penerapan diagnosa keperawatan yaitu jelas dan mudah dimengerti, Merupakan respon dari pasien terhadap situasi/keadaan yang dihadapi, Berorientasi kepada pasien, Spesifik dan akurat (Actual/Resiko), Dapat diatasi oleh intervensi keperawatan.

Diagnosis keperawatan memiliki 2 kompinen utama, yaitu Masalah (Problem) atau Label Diagnosis dan Indikator Diagnostik. 
1. Masalah (Problem)

Masalah merupakan label diagnosis keperawatan yang menggambarkan inti dari respon klien terhadap kondisi kesehatan atau proses kehidupannya. Label diagnosis ini terdiri dari Deskriptor atau penjelas dan Fokus Diagnostik.

\section{Indikator Diagnostik}

Indikator diagnostik terdiri dari penyebab, tanda/gejala, dan faktor resiko dengan uraian sebagai berikut.

a. Penyebab (Etiology)

Merupakan faktor-faktor yang mempengaruhi perubahan status kesehatan. Etiologi ini dapat mencakup 4 kategori, yaitu;

- Fisiologis, Biologis atau Psikologis,

- Efek Terapi/Tindakan,

- Situasional (lingkungan atau personal)

- Maturasional

b. Tanda (Sign) dan Gejala (Symptom)

Tanda merupakan data objektif yang diperoleh dari hasil pemeriksaan fisik, pemeriksaan laboratorium dan prosedur diagnostik. Sedangkan gejala merupakan data subjektif yang diperoleh dari hasil anamnesis atau pengkajian. Tanda/gejala ini dikelompokan menjadi 2 kategori, yaitu:

- Tanda/Gejala Mayor: Ditemukan sekitar 80\% - 100\% untuk validasi diagnosis.

- Tanda/Gejala Minor: Tidak harus ditemukan, namun jika ditemukan dapat mendukung penegakan diagnosis.

c. Faktor Resiko (Risk Factor)

Merupakan kondisi atau situasi yang dapat meningkatkan kerentanan klien dalam mengalami masalah kesehatan atau proses kehidupannya. Indikator diagnosis ini akan berbeda-beda pada masing-masing macam jenis diagnosis.

- Pada diagnosis aktual, indikator diagnostiknya terdiri dari penyebab dan tanda/gejala. 
- Pada diagnosis resiko, tidak memiliki penyebab dan tanda/gejala, melainkan hanya faktor resiko saja.

- Pada diagnosis promosi kesehatan, hanya memiliki tanda/gejala yang menunjukan kesiapan klien untuk mencapai kondisi yang lebih optimal.

Proses penerapan diagnosis (diagnostic process) adalah suatu proses yang sistematis yang terdiri dari 3 tahap yaitu, analisis data, identifikasi masalah dan perumusan diagnosis. Proses penegakan diagnosis keperawatan diuraikan sebagai berikut;

\section{Analisis Data}

Sebelum menganilis data, pastikan perawat sudah mengumpulkan data terlebih dahulu. Tahap pertama dalam proses penegakan diagnosis keperawatan adalah Analisis data yang dilakukan dengan tahapan sebagai berikut ini.

a. Bandingkan data dengan nilai normal/rujukan

Data-data yang didapatkan dari pengkajian, bandingkan dengan nilai-nilai normal dan identifikasi tanda/gejala yang bermakna, baik tanda/gejala mayor ataupun tanda/gejala minor.

\section{b. Kelompokkan data}

Tanda/gejala yang dianggap bermakna, dikelompokan berdasarkan pola kebutuhan dasar yang meliputi; respirasi, sirkulasi, nutri/cairan, eliminasi, aktivitas/istirahat, neurosensori, reproduksi/seksualitas, nyeri/kenyamanan, integritas ego, pertumbuhan/perkembangan, kebersihan diri, penyuluhan/pembelajaran interaksi sosial, dan keamanan/proteksi.

2. Identifikasi Masalah

Setelah data dianalisis, perawat dan klien bersama-sama mengidentifikasi masalah, mana masalah yang aktual, resiko dan /atau promosi kesehatan.

3. Perumusan Diagnosis Keperawatan

Perumusan atau penulisan diagnosis disesuaikan dengan jenis diagnosis keperawatannya. Terdapat 2 metode perumusan diagnosis, yaitu;

a. Penulisan 3 Bagian (3 Parts Format) 
Metode penulisan ini terdiri dari Masalah, Penyebab dan Tanda/Gejala dan hanya dilakukan pada diagnosis aktual saja. Formulasi diagnosis keperawatan penulisan 3 bagian adalah sebagai berikut: Masalah berhubungan dengan Penyebab dibuktikan dengan Tanda/Gejala. Frase 'berhubungan dengan' dapat disingkat b.d dan frase 'dibuktikan dengan' dapat disingkat d.d.

Contoh Penulisan: Bersihan jalan nafas tidak efektif b.d spasme jalan nafas d.d batuk tidak efektif, sputum berlebih, mengi, dispnea dan gelisah.

\section{b. Penulisan 2 Bagian (2 Parts Format)}

Metode penulisan ini dilakukan pada diagnosis resiko dan diagnosis promosi kesehatan, dengan formulasi sebagai berikut:

(1) Diagnosis Resiko: Masalah dibuktikan dengan Faktor Resiko

Contoh Penulisan: Resiko aspirasi dibuktikan dengan tingkat kesadaran menurun.

(2) Diagnosis Promosi Kesehatan: Masalah dibuktikan dengan Tanda/Gejala

Contoh Penulisan: Kesiapan peningkatan eliminasi urin dibuktikan dengan pasien mengatakan ingin meningkatkan eliminasi urin, jumlah dan karakteristik urin normal.

Sistem Klasifikasi diagnosa keperawatan salah satunya adalah NANDA (North American Nursing Diagnoses Association), seperti yang ditunjukkan dalam NANDA: Nursing Diagnoses and Classification 1992 - 1993. Dalam NANDA tersebut terdapat Sembilan pola respon manusia: pertukaran, berkomunikasi, berhubungan, menilai, memilih, pergerakkan, persepsi, mengetahui, dan perasaan. Akan tetapi, NANDA belum optimal mengakomodasikan diagnosis keperawatan di area keperawatan komunitas (kelompok dan masyarakat), sehingga digunakan juga rumusan ICNP (International Classification for Nursing Practice). International Council of Nurses (ICN) sejak tahun 1991 telah mengembangkan suatu sistem klasifikasi yang disebut dengan International Classification for Nursing Practice (ICNP).Sistem klasifikasi ini tidak hanya mencakup klasifikasi intervensi dan tujuan (outcome) keperawatan saja. Lebih dari itu, sistem klasifikasi ini disusun untuk mengharmonisasikan terminologi-terminologi keperawatan yang digunakan diberbagai negara diantaranya seperti ;

- Clinical Care Classification (CCC), 
- North American Nursing Diagnosis Association (NANDA),

- Home Health Care Classification (HHCC),

- Systematized Nomenclature of Medicine Clinical Terms (SNOMED CT),

- International Classification of Functioning, Disability and Health (ICF),

- Nursing Diagnosis System of the Centre for Nursing Development and Research (ZEFP)

- Omaha System.

ICNP membagi diagnosis keperawatan menjadi 5 kategori, yaitu Fisiologis, Psikologis, Perilaku, Relasional dan Lingkungan.

- Fisiologis: Respirasi, sirkulasi, nutrisi dan cairan, eliminasi, aktivitas dan istirahat, neurosensory.

- Psikologis: Nyeri dan kenyamanan, Integritas ego, pertumbuhan dan perkembangan

- Perilaku: Kebersihan diri, Penyuluhan dan Pembelajaran.

- Relasional: Interaksi Sosial

- Lingkungan: Keamanan dan Proteksi

\section{PENUTUP}

Diagnosa keperawatan merupakan Pernyataan yang jelas mengenai status kesehatan/masalah aktual atau resiko dalam rangka mengidentifikasi dan menentukan intervensi keperawatan untuk mengurangi, menghilangkan atau mencegah masalah kesehatan klien yang ada pada tanggung jawabnya.

Seorang perawat harus mampu melakukan diagnosis keperawatan ditetapkan berdasarkan analisis data yang diperoleh dari pengkajian keperawatan klien. Diagnosis keperawatan memberikan gambaran tentang masalah atau status kesehatan klien yang aktual dan kemungkinan akan terjadi, dimana pemecahannya dapat dilakukan dalam batas wewenang perawat.

\section{REFERENSI}

Carpenito, M., Lynda, J. (2012). Buku Saku Diagnosis Keperawatan. Jakarta: EGC 
Dermawan, D. (2012). Proses Keperawatan Penerapan Konsep dan Kerangka Kerja. Yogyakarta: Gosyen Publishing.

Harnilawati. (2013). Konsep dan Proses Keperawatan Keluarga. Sulawesi Selatan: Pustaka As Salam

Herdman, T.H. \& Shigemi, K. (2018). NANDA International Nursing Diagnoses: Definitions and Classification. Jakarta: EGC.

Hermawan, I. (2019). Metodologi Penelitian Pendidikan Kuantitatif, Kualitatif, dan Mixed Methode. Kuningan: Hidayatul Quran

Ibrahim, K., Novieastari, E (eds). (2017). Dasar - Dasar Keperawatan. Singapore: Elsevier

Muhith, A. (2015). Pendidikan Keperawatan Jiwa. Yogyakarta: CV Andi Offset

Parellangi A. (2018). Home Care Nursing - Aplikasi Praktik Berbasi Evidence-Based. Yogyakarta: CV. Andi Offset

Simamora, R. H., Bukit, E., Purba, J. M., \& Siahaan, J. (2017). Penguatan kinerja perawat dalam pemberian asuhan keperawatan melalui pelatihan ronde keperawatan di rumah sakit royal prima medan. Jurnal pengabdian kepada masyarakat, 23(2), 300-304.

Simamora, R. H. (2019). Socialization of Information Technology Utilization and Knowledge of Information System Effectiveness at Hospital Nurses in Medan, North Sumatra. Editorial Preface From the Desk of Managing Editor..., 10(9).

Standar Diagnosis Keperawatan Indonesia (ed. 1). Jakarta: DPP PPNI

Sunaryo. (2015). Asuhan Keperawatan Gerontik. Yogyakarta: CV Andi Offset 